\title{
Immunohistochemical study of the inflammatory response of the dental pulp
}

\author{
Ana Sotirovska Ivkovska ${ }^{1 *}$, Efka Zabokova-Bilbilova ${ }^{1}$, Zlatko Georgiev $^{1}$, \\ Ljube Ivkovski ${ }^{2}$ \\ ${ }^{\prime}$ Department of Pediatric and Preventive Dentistry, Faculty of Dentistry, University "Ss. Cyril and Methodius", \\ Majka Tereza 43, 1000 Skopje, Republic of Macedonia \\ ${ }^{2}$ Histolab, Diagnostic Laboratory for Histopathology and Clinical Cytology, \\ 50 Divizija 34, 1000 Skopje, Republic of Macedonia
}

Received: August 2015; Accepted: October 2015

\begin{abstract}
Defense reactions of the dental pulp involve a variety of biological reactions, in which the immune system plays a very important role. The class II major histocompatibility complex (MHC) molecule expressing cells, termed dendritic cells and lymphocytes in human dental pulp are highly sensitive to exogenous antigenic stimuli. Their drastic changes in number and localization are induced by dental caries. This study investigated the responses of the immune system in two different clinical conditions: shallow and deep cavities. Cells were identified immunohistochemically by using the following monoclonal antibodies: HLA-DR, CD45RO and CD20. Initial pulpal response was characterized by a localized accumulation of HLA-DR antibody-positive cells in the pulp tissue beneath the dentinal tubules communicating with the caries lesion. In the pulp of progressed caries, a large number of HLA-DR-positive cells was observed with a marked increase of other kinds of immunocompetent cells. This might indicate the occurrence of antigen presentation locally in the pulp tissue, which is very important for the immune response.

Results obtained in this study demonstrated that dental pulps respond to the progression of the carious lesion and cellular and humoral immune responses occur in the pulp tissue.
\end{abstract}

Keywords: human dental pulp, dendritic cells, lymphocytes, dental caries, immunohistochemistry

\section{Introduction}

In the oral cavity a number of elements are present which potentially can be injurious to the pulp (Bergenholtz, 1991; Cox, 1992; Ebersole, 1992). It is now well documented that bacteria and bacterial by-products are associated with most pulpal disease processes, activating various forms of immune reactions by acting as antigens (Fleming, 1985; Izumi, et al., 1995). Manifestations of these responses are governed by a locally provided immune sys- tem which is specifically adapted to the anatomical features of the dental pulp.

Antigens are recognized and processed during the initial defense of the dental pulp. The presence of immunosurveillance components in the pulp was unveiled by the recent discovery of antigen-presenting cells that are capable of inducing an immune response by presenting processed foreign antigens to T-lymphocytes (Izumi, et al., 1996; Jontell, et al., 1988; Jontell, et al., 1998). These cells are believed to be associated with recognition of foreign antigens in non-lymphoid organs (Jontell, et al., 1992; Jon-

*anasotirovska@yahoo.com 
tell, et al., 1994). Dental pulp is equipped with major histocompatibility complex (MHC) class II molecule-expressing cells for initiating immune responses to exogenous antigenic stimuli. In intact teeth, they are distributed mainly in and around the layer of odontoblasts and are called pulpal dendritic cells. Drastic changes in their localization are induced by human dental caries (Yoshiba, et al., 1996; Kamal et al., 1997; Jontell, et al., 1991; About, et al., 2001) and after cavity preparation in rats (Ohshima, et al., 1995; Tanabe, et al., 2002; Okiji, et al., 1997 Murray, et al., 2002). Analysis of these data suggests that class II molecule-expressing cells are highly sensitive to antigenic stimuli penetrating dentinal tubules (Kim, et al., 1998; Kamal et al., 2000).

Caries attack also induces changes in the distribution of lymphocytes; they become concentrated beneath the carious lesions (Sakamoto, et al., 1992; Izumi, et al., 1995). Following the exogenous invasion of microorganisms, host defence reactions, such as inflammatory and immunological reactions, take place in the pulp in order to eliminate the foreign pathogens and to maintain the local homeostasis in the pulp. (Cooper, et al., 2010). Interactions between lymphocytes and MHC class II molecule-expressing cells have been shown in pulpal inflammation (Farges, et al., 2013).

The focus of this paper is to investigate pulpal responses in carious teeth with shallow and deep cavities and to understand how and which immmunocompetent cells infiltrate the pulp in association with the development of carious lesions and the distribution of MHC class II moleculeexpressing cells and lymphocytes.

\section{Material and method}

We have examined 60 human teeth from patients at the age of 9 to 14 years. Teeth were extracted from various therapeutic reasons (mostly from orthodontic reason), and immediately cut longitudinally; pulp tissue was extirpated and fixed in formalin for 24 hours at $4{ }^{\circ} \mathrm{C}$. The specimens were embedded in paraffin, according to standardized laboratory procedure. Sections were cut at $5 \mu \mathrm{m}$ thickness and stained by the streptavidin-biotin complex immunoperoxidase method. Cells were identified immunohistochemically by using the following monoclonal antibodies: HLA-DR (for dendritic cells), CD45RO (for memory Tlymphocytes) and CD20 (for B-lymphocytes).

To verify our hypothesis, we analyzed pulpal responses in two different clinical conditions: shallow ( $n=30$, pulp with caries in dentin, about $2-3 \mathrm{~mm}$ from the pulp chamber) and deep cavities $(\mathrm{n}=30$, pulp with caries deep into the dentin, $0.5-1.5 \mathrm{~mm}$ from the pulp chamber).

The depth of the carious lesion was determined by the pigmentation of hard tissues.

The main numbers of dendritic cells, T-cells and B-cells in each group were statistically analysed with ANOVA.

\section{Results}

The number of antigen-presenting and immunocompetent cells in each group is shown in Table 1 and Fig. 1.

Table1. Number of HLA-DR, CD45RO and CD20 antibody-positive cells in dental pulp in shallow and deep cavities

\begin{tabular}{lcc}
\hline \hline $\mathrm{N}$ & Group 1 & Group 2 \\
& 30 & 30 \\
\hline HLA-DR & 5.0 & 22.1 \\
CD45RO & 19.5 & 89.6 \\
CD20 & 4.7 & 51.2 \\
\hline
\end{tabular}

Values are means \pm SEM; $N$ - number of samples

In shallow dentinal lesions a few HLA-DR cells were present and they were distributed mainly around an odontoblast layer and along the dentin-pulp border (Fig. 2).

As the caries lesion advanced, cells expanded toward the center of the pulp. Under deeper cavities HLA-DR-positive cells were dispersed among affected odontoblasts and they have displaced odontoblasts below the cavities. Cells were markedly increased, but not significantly (Fig. 3).

An increase of CD45RO-positive cells T-lymphocytes was observed in majority of specimens in teeth with moderate to deep caries. These cells were concentrated below the para-odontoblastic region, forming an aggregation. The number of T-cells was markedly increased in deep cavities and significant differences were evident between group 1 and 2 ( $<<0.01$ ), (Fig.4 and Fig.5).

The number of CD20-positive B-lymphocytes was much smaller than that of T-lymphocytes in most specimens. A considerable number of CD20-positive cells was detected among lymphocytes forming clusters in deeper cavities, with significant differences between group 1 and 2 (p<0.01), (Fig. 6 and Fig. 7).

\section{Discussion}

Primary etiological factor of pulpal disease is penetration of microorganisms into the pulp, mainly via carious dentin. Following the exogenous invasion of microorganisms, host defence reactions, such as inflammatory and immunological reactions may, take place in the pulp in order to eliminate the foreign pathogens and to maintenance the local homeostasis in the pulp (Goldberg, et al., 2008). Defence reactions of the dentin/ pulp complex involve a variety of biological systems, in which the immune system plays a very important role (Nahn, et al., 2007). The recognition of B and T-lymphocyte subpopulations in tissues was made possible by the advent of immunohistological staining techniques using monoclonal antibodies against specific surface 


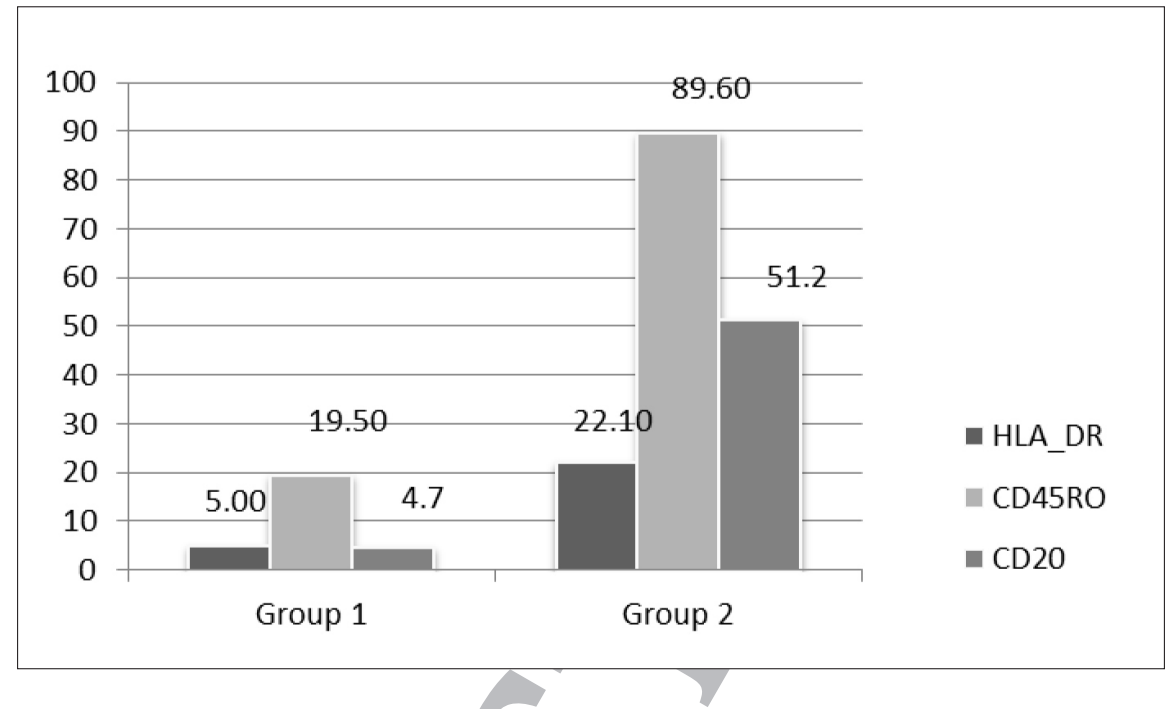

Fig. 1. Number of HLA-DR, CD45RO and CD20 antibody-positive cells in dental pulp in shallow and deep cavities.

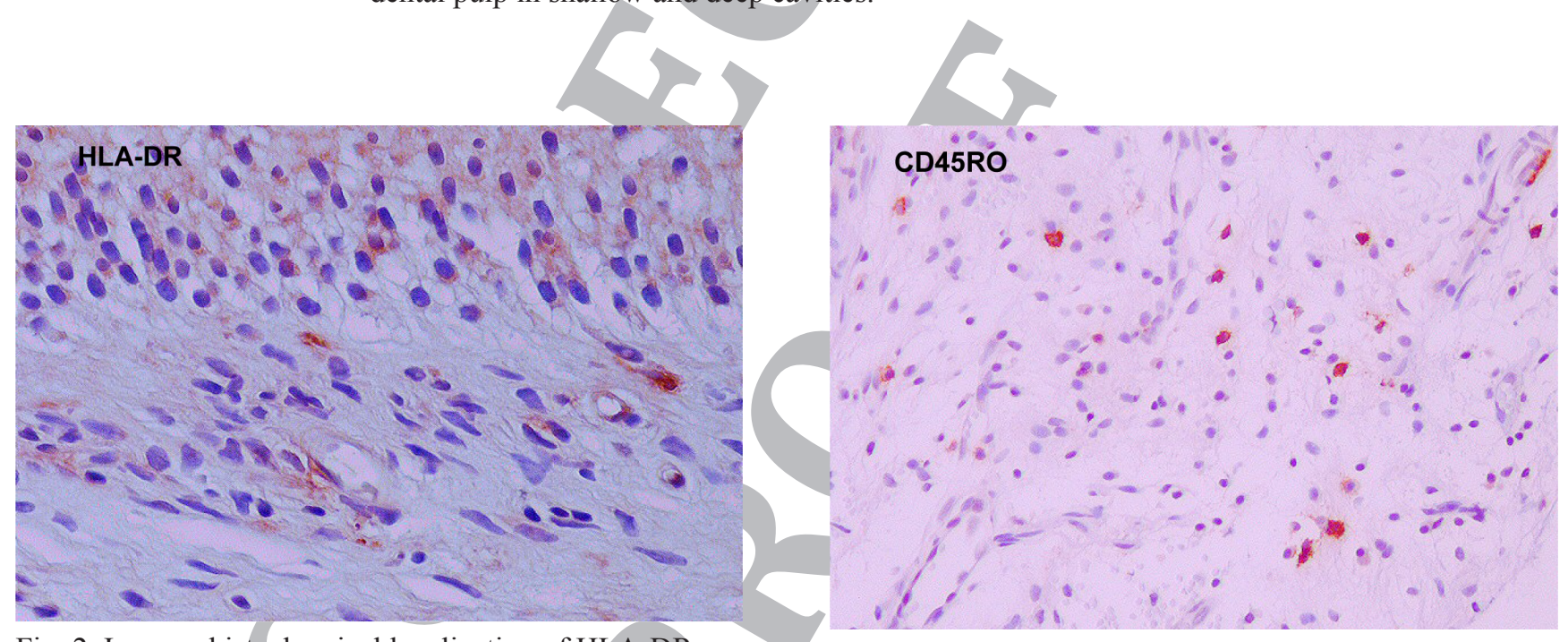

Fig. 2. Immunohistochemical localization of HLA-DR positive cells in the pulp with shallow cavities.

Fig. 4. Immunohistochemical localization of CD45RO positive cells in the pulp with shallow cavities.

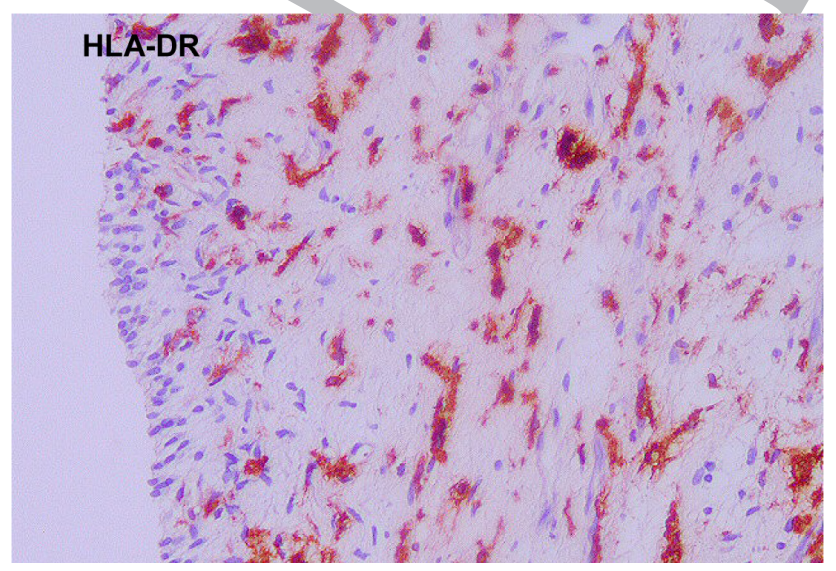

Fig. 3. Immunohistochemical localization of HLA-DR positive cells in the pulp with deep cavities.

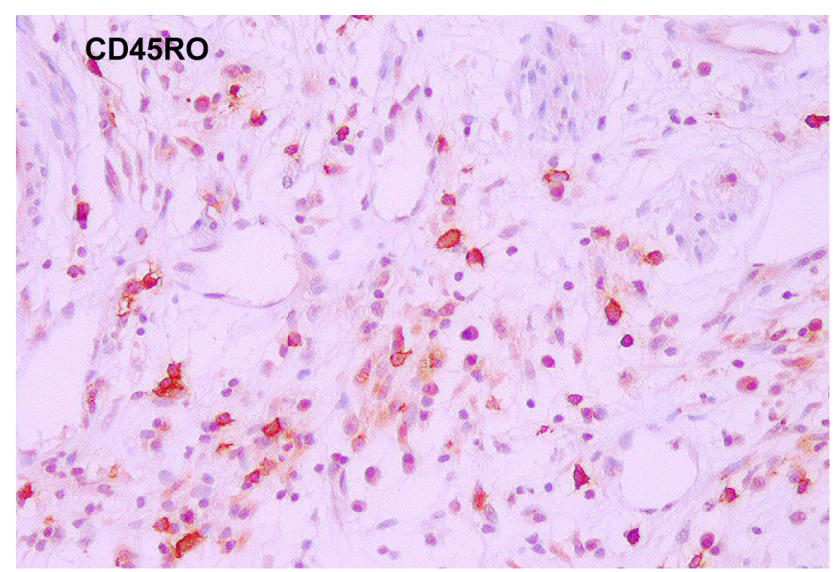

Fig. 5. Immunohistochemical localization of CD45RO positive cells in the pulp with deep cavities. 


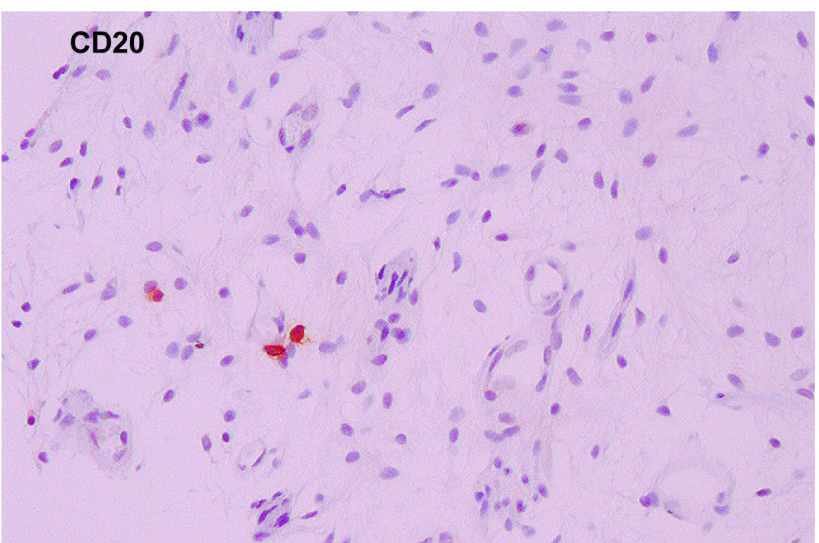

Fig. 6. Immunohistochemical localization of $\mathrm{CD} 20$ positive cells in the pulp with shallow cavities. molecules on lymphocytes. Three monoclonal antibodies directed to antigen-presenting and immunocompetent cells were used to study pulpal tissues. This study describes the quantitative and qualitative changes of dendritic and immunocompetent cells in the human dental pulp with developing carious lesions.

T-lymphocytes showed an increase even in teeth with shallow dentinal caries, while B-lymphocytes increased only in teeth with deep caries. We can assume from these findings that during the carious process B-lymphocytes appear later than T-lymphocytes at the site of carious injury. This give support to the central role of T-lymphocytes in the initiation of pulpal specific immunity following exposure to protein antigens. Signals provided by T-lymphocytes most likely are prerequisite of other antigen specific effector cells such as B-lymphocytes. Distribution of HLA-DR positive cells in human carious teeth has been reported (Sakurai, et al., 1999; Yoshiba, et al., 1996; Rescigno, et al., 2001). In teeth with deep dentinal caries there was a marked localized accumulation of these cells at the pulpal region immediately subjacent to the pulpal end of the carious dentinal tubules. The accumulation in this position indicates that these cells are responding actively to incoming carious bacterial antigens that permeated dentinal tubules. In most specimens, localized accumulation of T-lymphocytes was noticeable, while there was only a small number of B-lymphocytes in and around the area of the dendritic cells accumulation. These findings suggest an initial critical role of a local interaction between pulpal dendritic cells and memory T-lymphocytes. Sotirovska-Ivkovska, et al., 2000; Sotirovska-Ivkovska, et al., 2001). This interaction may result in the activation of T-lymphocytes and dendritic cells, which than facilitates the mobilization and activation of different types of effector cells and triggers a cascade of immunopathologic events involved in the pulpal pathological processes associated with dental caries.

This study provides evidence that cavity depth

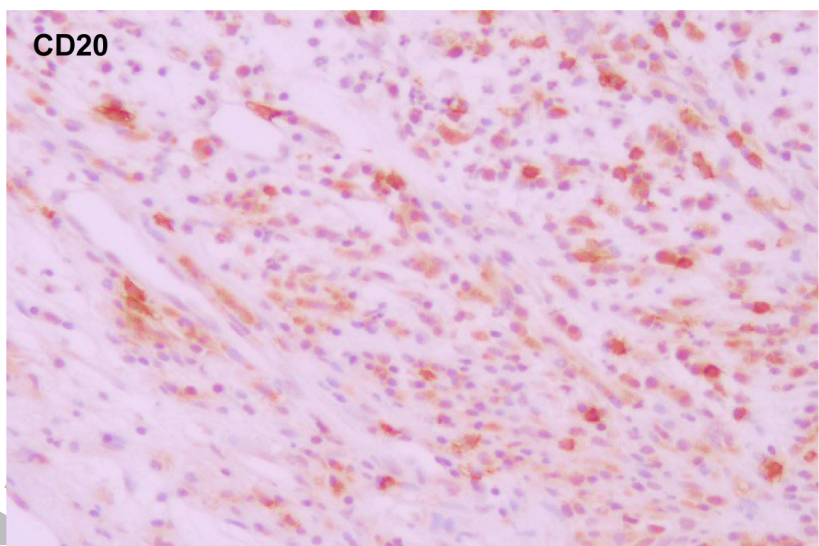

Fig. 7. Immunohistochemical localization of $\mathrm{CD} 20$ positive cells in the pulp with deep cavities.

influences the distribution of HLA-DR-positive dendritic cells and lymphocytes. Reduction in the thickness of residual dentin had an impact on the distribution of the cells. These changes are in agreement with findings from studies on the distribution of dendritic cells and lymphocytes in human teeth. Early pulpal response to bacterial diffusion of bacterial products through dentinal tubules elicits the influx of dendritic cells, T-lymphocytes and rare B-lymphocytes. As the infection is coming closer to the pulp, the response assumes a typical mixed character, consisting of T-cells and B-cells.

\section{Conclusion}

Our present findings indicate that human dental pulp is equipped with a functional immune response against microbial insults from dental caries.

In the initial stage of caries infection, an immunoresponse mediated by class-II-expressing cells is initiated in human dental pulp.

T-lymphocyte-mediated immune responses has central role in the initiation of pulpal specific immunity following exposure to protein antigens. Signals provided by T-lymphocytes most likely are prerequisite for the activation of other antigen specific effectors cells such as B-lymphocytes.

\section{References}

About, I., Murray, P.E., Franguin, J.C., Remusat, M., Smith, A.J., 2001. The effect of cavity restoration variables on odontoblast cell numbers and dental repair. J. Dent. 29,109117.

Bergenholtz, G., Nagaoka, S., Jontell, M., 1991. Class II antigen expressing cells in experimentally induced pulpitis. Int. Endod. J. 24, 8-14.

Cooper, P.R, Takahashi, Y., Graham, L.W., Simon, S., Imazato, S., Smith, A.J, 2010. Inflammation-regeneration interplay in 
the dentine-pulp complex. J. Dent. 38, 687-697.

Cox, D.S., 1992. Inflammation, hypersensitivity, and regulatory mediators. In: Contemporary oral microbiology and immunology. Slots, J., Taubman, M.A., (Eds.), Mosby, Baltimore, pp 135-143.

Ebersole, J.L., 1992. Cells and tissues of the immune system. In: Contemporary oral microbiology and immunology. Slots J, Taubman, M.A., (Eds.), Mosby, Baltimore, pp 78-116.

Farges, J.C., Alliot-Licht B., Baudouin, C., Msika, P., Bleicher, F., Carrouel, F., 2013. Odontoblast control of dental pulp inflammation triggered by cariogenic bacteria. Front. Physiol. 4, 326.

Fleming, S., 1985. Immunophysiology: the Immune Response. In: Muir's Textbook of Pathology. Anderson, J.R., (Eds.), 12th ed, 6.1-6.40. Arnold, Baltimore.

Goldberg, M., Farges, J.C., Lacerda-Pinheiro, S., Six, N., Jegat, N., Decup, F., Septier, D., Carrouel, F., Durand. S., Chaussain-Miller, C., Denbesten, P., Veis, A., Poliard, A., 2008. Inflammatory and immunological aspects of dental pulp repair. Pharmacol. Res. 58(2), 137-147.

Izumi, T., Kobayashi, I., Okamura, K., Matsuo, K., Kiyoshima, T., Ishibashi, Y., Inoue, H., Sakai, H., 1996. An immunohistochemical study of HLA-DR and $\alpha_{1}-$ antichimotrypsin-positive cells in the pulp of human noncarious and carious teeth. Arch. Oral. Biol. 41(7), 627-630.

Izumi, T., Kobayashi, I., Okamura, K., Sakai, H., 1995. Immunohistochemical study on the immunocompetent cells of the pulp in human non-carious and carious teeth. Arch. Oral. Biol. 40(7), 609-614.

Jontell, M., Bergenholtz, G., 1992. Accessory cells in the immune defence of the dental pulp. Proc. Finn. Dent. Soc. 88(suppl.1), 345-56.

Jontell, M., Bergenholtz, G., Scheynius, A., Ambrose, W., 1988. Dendritic cells and Macrophages expressing class II antigens in the normal rat incisor pulp. J. Dent. Res. 67(10), 12631266.

Jontell, M., Eklog, C., Dahlgren, U.I., Bergenholtz, G., 1993. Difference in capacity between macrophages and dendritic cells from rat incisor pulp to provide accesory signals to concavalin-A-stimulated T-lymphocytes. J. Dent. Res. 73(5), 1056-1060.

Jontell, M., Jiang, W.H., Bergenholtz, G., 1991. Ontogeny of class II antigen expressing cells in rat incisor pulp. Scand. J. Dent. Res. 99, 384-389.

Jontell, M., Okiji, T., Dahlgreen, U., Bergenholtz., G., 1998. Immune defence mechanisms of the dental pulp. Crit. Rev. Oral. Biol. Med. 9(2), 179-200.

Kamal, A.M.M., Okiji, T., Kawashima, N., Suda, N., 1997. Defence responses of dentin/pulp complex experimentally induced caries in rat molars: An immunohistochemical study on kinetics of pulpal Ia antigen-expressing cells and macrophages. J. Endod. 23(2), 115-120.
Kamal, A.M., Okiji, T., Suda, H., 2000. Response of class II molecule-expressing cells and macrophages to cavity preparation and restoration with 4-META/MMA-TBB resin. Int. Endod. J. 33:367-373.

Kim, S., Trowbridge, H.O., 1998. Pulpal reaction to caries and dental procedures. In: Pathways of the pulp, $7^{\text {th }}$ ed. Mosby, Baltimore.

Murray, P., Windsor, J.L., Thomas, W., Smyth, T., Hafez, A., Cox, C., 2002. Analysis of pulpal reactions to restorative procedures, materials, pulp capping and future therapies. Crit. Rev. Oral. Biol. Med. 13(6), 509-520

Nahn, C.L., Liewehr, F.R., 2007. Update on the adaptive immune responses of the dental pulp. J. Endod. 33(7), 773-781.

Ohshima, H., Sato, O., Kawahara, I., Maeda, T., Takano, Y., 1995. Responses of immunocompetent cells to cavity preparation in rat molars: an immunohistochemical study using OX6monoclonal antibody. Connect Tissue Res. 32:303-311.

Okiji, T., Jontell, M., Belichenko, P., Dahlgren, U., Bergenholtz, G., Dahlstrom, A., 1997. Structural and functional association between substance $\mathrm{P}$ and Calcitonin gene-related peptide immunoreactive nerves and accessory cells in the rat dental pulp. J. Dent. Res. 76(12), 1818-1824.

Rescigno, M., Urbano, M., Valzasina, B., Francolini, M., Rotta, G., Bonasio, R., et al: 2001. Dendritic cells express tight junction proteins and penetrate gut epithelial monolayers to sample bacteria. Nat. Immunol. 2(4), 361-367.

Sakamoto, M., Sanjo D., 1992. An immunohistochemical study on human dental pulp in different depth of carious lesion. Jpn. J. Conser. Dent. 35, 828-835.

Sakurai, K., Okiji, T., Suda, H., 1999. Co-increase of nerve fibers and HLA-DR-and/or factor-XIIIa-expressing dendritic cells in dentinal caries-affected regions of the human dental pulp: An immunohistochemical study. J. Dent. Res. 78(10), 15961608 .

Sotirovska-Ivkovska, A., Ivkovski, L., 2001. Immunohistochemical study of HLA-DR-positive cells and macrophages in unerupted and erupted normal and carious human teeth. Caries Res. 35(4): 284

Sotirovska-Ivkovska, A., Ivkovski, L., Bajraktarova B., Georgiev Z., Zabokova-Bilbilova, E., 2000. An immunohistochemical study of antigen-presenting cells in the human dental pulp. Int. Dent. J. (Supplement) 6, 353.

Tanabe, K., Yoshiba, N., Iwaku, M., Ozava, H., 2002. Immunohistochemical study on pulpal response in rat molars after cavity preparation by Er:YAG laser. Eur. J. Oral Sci. 110, 237-245.

Yoshiba, N., Yoshiba, H., Nakamura, H., Iwaku, M., Ozawa, H., 1996. Immunohistochemical localisation od HLA-DR positive cells in unerupted and erupted normal and carious human teeth. J. Dent. Res. 75(8), 1585-1589. 


\title{
Имунохистохемиска студија за воспалителниот одговор на забната пулाа
}

\author{
Ана Сотировска Ивковска ${ }^{1 *}$, Ефка Жабокова-Билбилова ${ }^{1}$, Златко Георгиев ${ }^{1}$, \\ Љубе Ивковски ${ }^{2}$
}

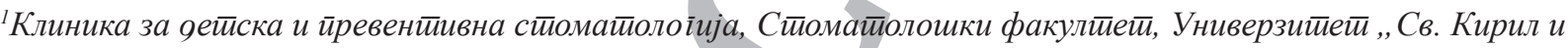
Мейояиј“, Мајка Тереза 43, 1000 Скойје, Рейублика Макеоонија

${ }^{2}$ Хистиолаб, Дијаїносиичкка лаборайорија за хистиойайолоіија и клиничка иииологіија, 50 Дивизија 34, 1000 Скойје,

Рейублка Макеоонија

Клучни зборови: хумана забна пулпа, дендритични клетки, лимфоцити, забен кариес, имунохистохемија

Одбранбените реакции на забната пулпа вклучуваат различни биолошки реакции, во кои имунолошкиот систем игра многу важна улога. Молекулата класа II од главниот хистокомпатибилен комплекс (MHC) која ја изразуваат клетките, наречени дендрични клетки и лимфоцитите во хуманата дентална пулпа, се високо чувствителни на егзогените антигенски стимули. Нивните драстични промени во бројот и локализацијата се предизвикани од појавата на забниот кариес. Оваа студија го испитуваше одговорот на имунолошкиот систем во две различни клинички состојби: кај плитки и длабоки кариозни лезии. Клетките беа идентификувани имунохистохемиски со користење на следниве моноклонални антитела: HLA-DR, CD45RO и CD20. Првичниот пулпин одговор се карактеризираше со локализирана акумулација на позитивни клетки од HLA-DR антитела во ткивото на пулпата под дентинските тубули кои се поврзани со кариозната лезија. Во пулпата кај напреднатата кариозна лезија, голем број на HLADR-позитивни клетки беа забележани со истовремено зголемување на други видови на имунокомпетентни клетки. Ова може да укаже на појавата на антигенска презентација локално во ткивото на пулпата, што е многу важно за имунолошкиот одговор.

Резултатите добиени во оваа студија покажаа дека забната пулпа реагира на прогресијата на кариозната лезија и клеточниот и хуморалниот имунолошки одговор се јавуваат во ткивото на пулпата. 